\title{
THE TRACEABILITY STUDY IN THE PROCESS OF MANUFACTURING THE CHEESE WITH ROMANO HARD PASTE
}

\author{
Mihaela-Adriana, TITA ${ }^{1}$, Adriana-Ioana, CIPARIU ${ }^{2}$ \\ 1“Lucian Blaga" University of Sibiu, Sibiu, Romania, mihaela.tita@ulbsibiu.ro \\ ${ }^{2}$ Lucian Blaga” University of Sibiu, Sibiu, Romania, adrianacipariu@ yahoo.com
}

\begin{abstract}
A constant concern of the scientific research in the field of food safety is the identification of methods, to determine in an objective way, the quality of the food, available on the market. The paper analyzes the traceability concept, the importance of traceability implementation of a traceability system, in an organization within the food chain.

KEYWORDS: traceability, traceability system, SQLite Manager.
\end{abstract}

\section{INTRODUCTION}

Among the wide range of dairy products, the cheese is the richest and the most varied group, which concentrate a large nutritional value per unit of mass, much higher comparing with the milk as such, or with other cultured milk products, being considered the food of the highest protein quality.

Cheese is a dairy food, fresh or matured, solid or semisolid, obtained from appropriate recipes after milk coagulation, being the result of a complex process of maturation, fermentationwhich must be controlled and directed.

Cheese nutrient and biological value depends on the chemical composition, that, in turn, is influenced by the assortment. [2]

Roman type cheese is a cheese typical of Italy, produced traditionally in Lazio and recently, in Sardinia.

Cheese paste is compact and easily pierced and the color varies from white to straw-yellow, more or less intense, derived from technical production conditions. The cheese taste is flavored, slightly piquant, savory for a meal cheese and strong piquant for grated cheese.

\section{ENSURING THE QUALITY OF THE CHEESE ROMANO}

Cheese Quality depends on the quality of raw materials and auxiliary materials used in its manufacturing.

Milk meant to the cheese manufacturing must meet the following requirements:

- $\quad$ it must come from healthy animals, fed up with rational quality feed, which do not provide different taste and odor to the milk;

- be in conformity from the microbiological point of view (reduced number of total germs and especially anaerobic sporogenous bacteria, type Clostridium, milk bacteria that are later bloating agents of the cheeses);
- the acidity be $16-20^{\circ} \mathrm{T}$ for cow's milk;

- $\quad$ avoid to use the milk in the first 8-10 days after SPARKLE PLENTY parturition and during the last 10-15 days of lactation; - do not contain antibiotics and antiseptics that have inhibitory effects on microorganisms which ensures maturation.

Quality control of milk intended for the cheese manufacturing involves:

- $\quad$ sensory analysis: color, taste, smell, appearance;

- physical-chemical analysis: degree of pollution, density, acidity, fat content, protein titer;

- microbiological analysis: reductive sample, fermentation sample, sample coagulation with rennet, the determination of the sporulent bacteria uploading;

- identification of mamitic milk (mastitis). The composition of the mamitic milk is characterized by a low content of casein and lactose, but increased soluble protein, blood serumalbumină, immunoglobulin and chlorides. The contents of $\mathrm{Mg}+2$ and $\mathrm{Ca}+2$ of mamitic milk are lower than in the normal one. In terms of enzyme activity, mamitic milk has a high activity of catalase, acid and alkaline phosphatase. [3]

\section{TRACEABILITY STUDY FOR MANUFACTURING THE ROMANO CHEESE}

\subsection{General aspects concerning the traceability}

A traceability system is a useful tool that helps an organization within a food chain to achieve the objectives set out in a management system.

The choice of a traceability system is influenced by regulations, product characteristics and expectations of the recipients.

The complexity of traceability system may vary depending on the product features and the objectives to be achieved.

The implementation by an organization, of the traceability system, depends on: 
- the organisation and products inherent technical limits (meaning the nature of the raw materials, the size of batches, procedures for the collection, transportation, processing and packaging methods);

- the implementation cost of such a system. [4]

The traceability of components are:

- The supplier traceability represented by all records and documents which can prove the origin of all raw materials, ingredients, additives, etc.;

- Process Traceability, represented by recordings made during the production technological process, which ensures the possibility to identify all of raw materials, ingredients, additives, from which it was obtained a specific product and operations they have suffered during the technological flow;

- The client traceability, to ensure identification of all product clients. [1]

Traceability systems should be able to present the product history and/or to locate a product in the food chain. Traceability systems contribute to research the cause of non-conformity and the ability to withdraw and/or recall products if necessary. Traceability systems can improve the suitable usage and confidence in information, efficiency and productivity of the organization.

Traceability systems should be:

- verifiable

- applied consistently,

- results-oriented,

- effective,

- $\quad$ with practical application. [4]

\subsection{The use of traceability systems to obtain Romano cheese}

In order to have an order and a production control it is necessary to implement a suitable system for the identification and traceability.

Creating the database required to achieve traceability has been carried out with the help of SQLite Manager program.

SQLite Manager is a relational database management system. This program is based on standard SQL language. The program offers several editions with different characteristics that can meet a variety of needs for users. [5]

This program was created to manage the databases within the enterprises. [6]

In order to achieve the implementation of a traceability system to obtain cheese Romano I have created and have used the following tables:

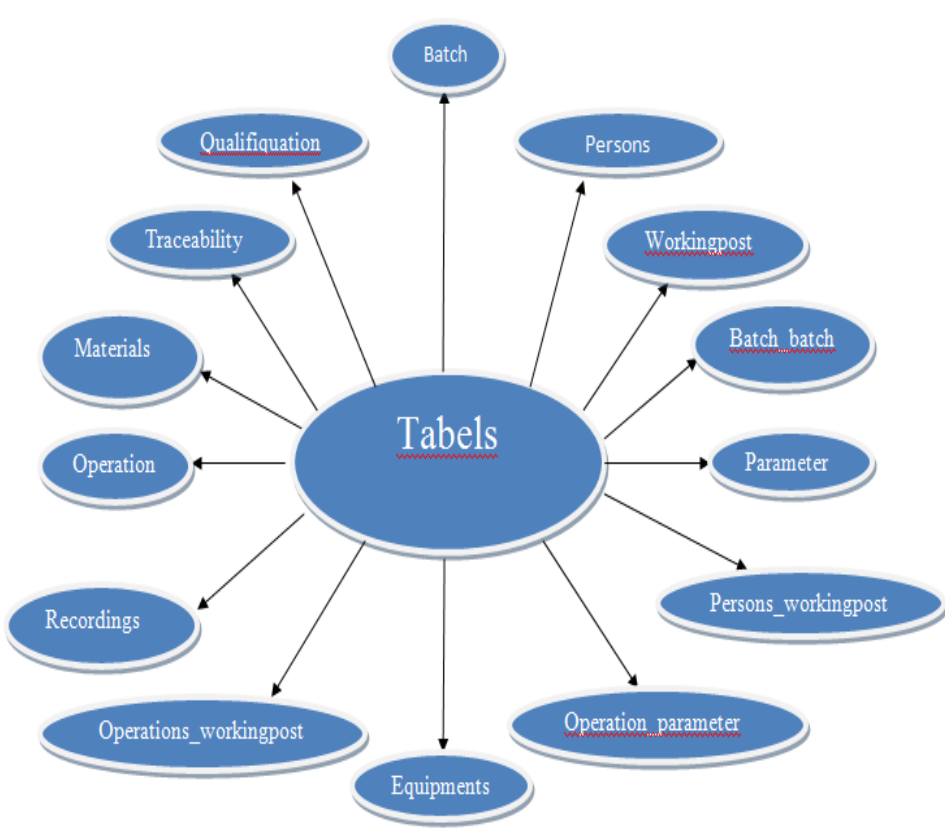

In the following table there are presented the products batches that I use for obtaining Romano cheese. For example I have set that the milk received in a day be considered a batch. Each material will receive a new code when it will be received at the factory.

Table 1. Batch

\begin{tabular}{|c|c|c|c|c|c|}
\hline TABLE lot & Search & Show All & & Add & Duplicat \\
\hline rowid & $\operatorname{cod}$ & material_cod & dimensiune & timp & \\
\hline 1 & L01 & lo1c & 38812,88 & 2014-05-01 11:15 & \\
\hline 2 & LOO2 & $104 \mathrm{c}$ & 37903,92 & |2014-05-01 11:24 & \\
\hline 3 & sMO1 & lo5c & 715,16 & $2014-05-0111: 24$ & \\
\hline 4 & |LO3 & lo6c & $\mid 37790,21$ & |2014-05-01 11:35 & \\
\hline 5 & Lo4 & losc & 37383,19 & $2014-05-0112: 25$ & \\
\hline 6 & |c001 & $10 c$ & |7156,04 & |2014-05-01 13:23 & \\
\hline 7 & zo1 & |11c & 29816,83 & 2014-05-01 13:23 & \\
\hline 8 & |c002 & $\mid 12 \mathrm{c}$ & |7134,57 & |2014-05-01 13:50 & \\
\hline 9 & $\mathrm{~B} 01$ & $13 c$ & 7674,52 & 2014-10-01 15:00 & \\
\hline 10 & $\mathrm{~B} 02$ & $16 c$ & 7506,26 & $2014-10-0115: 12$ & \\
\hline 11 & |СHO1 & $102 \mathrm{~b}$ & 0,508 & 2014-05-01 12:00 & \\
\hline 12 & СHO2 & $102 \mathrm{~b}$ & 15,24 & $2014-05-018: 00$ & \\
\hline 13 & |CACL01 & 104b & $\mid 7,26$ & |2014-05-01 12:00 & \\
\hline 14 & $\mathrm{CACLO}_{2}$ & 104b & 217,8 & $2014-05-017: 30$ & \\
\hline 15 & |DVSO1 & lo3b & $\mid 0,53$ & |2014-05-01 12:00 & \\
\hline 16 & DVSO2 & 103b & 15,9 & $2014-05-017: 45$ & \\
\hline 17 & SA01 & lo1b & 570,77 & 2014-05-01 13:51 & \\
\hline 18 & SAO2 & lo1b & $\mid 17123,1$ & 2014-05-01 8:30 & \\
\hline 19 & AMBBO1 & lo1e & 1,89 & |2014-10-01 15:10 & \\
\hline 20 & AMBO2 & lo1e & 56,7 & 2014-10-01 9:00 & \\
\hline
\end{tabular}

To follow the batches and performing the traceability I have made the table below where there are presented the three objectives which are followed within the traceability: what?, when?, where? (for example the batch "L01" lies between 07: 00-09: 31 at the workstation "ZRCC"). 
Table 2. Traceability

\begin{tabular}{|c|c|c|c|c|c|c|c|}
\hline TABLE trasabilitate & Search & Show All & & Add & Duplicate & Edit & Delete \\
\hline rowid & lot_cod & & postlueru_cod & in & & out & 田 \\
\hline 1 & | 01 & & ZRCC & 2014-05-017:00 & & |2014-05-019:31 & \\
\hline 2 & | 01 & & z201 & 2014-05-017:15 & & |2014-05-01 11:01 & \\
\hline 3 & | L01 & & ZRRD1 & 2014-05-017:30 & & |2014-05-01 11:15 & \\
\hline 4 & |L12 & & 2502 & 2014-05-017 7:40 & & $\mid 2014-05-0111: 24$ & \\
\hline 5 & L03 & & $Z P R 2$ & 2014-05-017:50 & & 2014-05-01 11:35 & \\
\hline 6 & |Lo4 & & $2 \mathrm{CO} 3$ & 2014-05-01 12:00 & & $\mid 2014-05-0112: 25$ & \\
\hline 7 & |coo1 & & $2 \mathrm{CO} 3$ & 2014-05-0112:30 & & $\mid 2014-05-01132: 23$ & \\
\hline 8 & |CO02 & & ZPRC & 2014-05-01 12:50 & & |2014-05-01 13:50 & \\
\hline 9 & |BO1 & & ZPBA & 2014-05-0113:51 & & 2014-11-01 15:N0 & \\
\hline 10 & B02 & & ZAOO3 & 2014-11-01 15:10 & & |2014-10-01 15:12 & \\
\hline 11 & |CHO2 & & zco3 & |2014-05-0112:00 & & |2014-05-01 12:.206 & \\
\hline 12 & |CACl01 & & zco3 & 2014-05-0112:00 & & |2014-05-01 12:206 & \\
\hline 13 & |DVSOI & & $2 \mathrm{cos}$ & 2014-05-0112:00 & & |2014-05-01 12:-206 & \\
\hline 14 & SAO1 & & |ZPBA & |2014-05-01 13:51 & & |2014-08-01 13.51 & \\
\hline 15 & AMBO1 & & ZAOOZ & 2014-11-01 15:10 & & |2014-11-01 15:12 & \\
\hline
\end{tabular}

\subsection{Exploiting the database}

For the incoming milk batch to identify the following:

- what workstations has passed the batch throught,

- technological operations that are performed on the batch,

- persons who have been in contact with this batch,

- batch size and what are the parameters that shall be checked for the mentioned batch.

SELECT operation. name, materials. name, name people, batch. size, workingpost, position, operations_workingpost, operations_workingpost. beginning the end, parameter. name, recordings. value, um.symbol. recordings. time stamp.

FROM operation, materials, persons, batch, workingpost, operations_workingpost, parameter, records, operation_parameteter, um

WHERE (operation. workingpost_code =workingpost.code.) AND (material_code $=$ materials.code)

AND(persoans_workingpost. persoans_code=individuals.code) AND (persoans_workingpost. workingpost_code = workingpost. doc) AND (batch code. L01 "LIKE") AND (operations_workingpostpostlucru. workingpost_code = workingpost. doc) AND (operations_workingpost. operations_code $=$ operations. code) AND (operations_parameter. _ code = surgery surgery. code) AND (code = parameter. operations_parameter. parameter_code) AND (operations_parameter_code = recordings. operations_parameter. doc) AND (value<valmin) and="" (="" value $="$ " valmax) AND (um parameter. _ code $=$ MU. code)
AND (records. timestamp $>=" 2014-05-01$ 7: 10") AND (<=”2014-05-01 7:25)

\subsection{Results and discusions}

\begin{tabular}{|l|c|c|c|c|c|c|c|c|}
\hline $\begin{array}{l}\text { Workingpost } \\
\text { code }\end{array}$ & name & $\begin{array}{c}\text { Persons } \\
\text { code }\end{array}$ & name & $\begin{array}{c}\text { Operati } \\
\text { on code }\end{array}$ & name & $\begin{array}{c}\text { Parameter } \\
\text { code } \\
\text { code }\end{array}$ & name & $\begin{array}{l}\text { valu } \\
\text { e }\end{array}$ \\
\hline ZRCC & Milk & 3 & $\begin{array}{c}\text { Bucur } \\
\text { Arina }\end{array}$ & 1 & $\begin{array}{c}\text { Qualitative } \\
\text { and } \\
\text { quantitative } \\
\text { reception }\end{array}$ & 3 & $\begin{array}{c}\text { Dried } \\
\text { substan } \\
\text { ce }\end{array}$ & 9,2 \\
\hline ZC01 & & 1 & $\begin{array}{c}\text { Avram } \\
\text { Cosmin }\end{array}$ & 2 & cleaning & & & 9,3 \\
\hline ZRD1 & & 4 & $\begin{array}{c}\text { Borcea } \\
\text { Bogdan }\end{array}$ & 3 & $\begin{array}{c}\text { Cooling } \\
\text { and storage } \\
\text { buffer }\end{array}$ & & & \\
\hline
\end{tabular}

The above table shows that the milk has gone through three workstations in the technological process, namely: through the reception qualitative and quantitative area, the cleaning area, cooling and storage area.

Technological operations that have been performed on the batch are: qualitative and quantitative reception, cleansing, cooling and storage milk buffer. They have also been identified three people who work at these workstations.

It is noticed that the parameter determined for milk is the dry substance and the values recorded for this are 9.2, 9.3, respectively.

\section{CONCLUSIONS}

As noted in the above table by exploiting that database it can be found out what is happening with each batch of products used to manufacture the Cheese with Romano Hard Paste.

\section{REFERENCES}

1. Păduraru, Gabriela, 2010, Managementul siguranţei alimentelor

2. Răducuţă, Ion, 2004, Filiera laptelui, Editura Universităţii Lucian Blaga, Sibiu

3. Tiţa, Mihaela-Adriana, 2005, Tehnologii şi utilaje în industria laptelui şi a produselor din lapte, vol.II, Editura Universităţii Lucian Blaga, Sibiu

4. ***, 2007, SR EN ISO 22005:2007 - Trasabilitatea în lanţul alimentar, Principii generale şi cerinţe fundamentale pentru proiectarea şi implementarea sistemului, Bucureşti

5. http://www.techopedia.com/definition/1243/sql-server. (2014)

6. http://searchsqlserver.techtarget.com/definition/SQLServer. (2014) 